\title{
Carbohydrate metabolism in the foetus and the newly born
}

\author{
By Heather J. Shelley, Nuffield Institute for Medical Research, \\ University of Oxford
}

Neonatal carbohydrate metabolism has been discussed in detail in two recent reviews (Walker, I968; Dawes \& Shelley, I968), covering work published up to I966. This article will attempt to summarize the information in these reviews, and bring it up to date by referring to work published in the last 2 years.

\section{Carbohydrate metabolism in the foetus}

Glucose crosses the placenta readily, probably by 'facilitated diffusion'; i.e. it travels in the direction of the diffusion gradient but at a faster rate than can be explained by simple diffusion. Since the foctal blood glucose concentration is usually about half that in the mother, glucose normally passes from mother to foetus. Measurements of the rate of glucose uptake in foetal lambs (Alexander, Britton \& Nixon, I $966 a$ ) and in babies at delivery (Wolf, Sabata, Frerichs \& Melichar, I969) suggest that it may be slightly greater than is needed to account for the foetal oxygen consumption. If most of the glucose is, in fact, oxidized, it may be the principal metabolic fuel of the foetus. This belief is strengthened by the relative impermeability of the placenta of diverse species to free fatty acids and ketone bodies, and by the fact that the evidence available suggests that although the foetus can oxidize ketone bodies, it is probably unable to degrade and oxidize fatty acids (Popják \& Beeckmans, r950; Koren \& Shafrir, I964; Alexander et al. 1966b, 1969; Shelley, I969; Wolf et al. 1969). Maternal amino acids are transported across the placenta against the concentration gradient, but again the foetus is unable to oxidize them (Yarnell, Nelson \& Wagle, I966); presumably amino acids are conserved for protein synthesis.

But not all the glucose which crosses the placenta is oxidized. Some must be used for lipogenesis; for which foetal liver has a large capacity, and some is stored as glycogen. The amount of lipid stored by the foetus varies enormously, but all species, including man, accumulate glycogen in the foetal liver and skeletal muscles (Table $\mathbf{~ ) . ~ E x c e p t ~ i n ~ t h e ~ r a b b i t , ~ t h e ~ g l y c o g e n ~ c o n c e n t r a t i o n ~ i n ~ t h e ~ f o e t a l ~ l i v e r ~ a t ~ t e r m ~}$ is about twice the usual adult concentration, but that in the skeletal muscles varies more widely, from ten times the adult concentration in the pig to four to five times the adult concentration in the sheep, monkey and man, and ncar-adult levels in rodents and the dog. In species with a short gestation (rat, rabbit, dog, guinea-pig) the liver glycogen remains low $(<5 \mathrm{mg} / \mathrm{g})$ until a few days before term, but in other species the concentration begins to rise at a much earlier stage of gestation; for instance in man the concentration has already reached $40-50 \mathrm{mg} / \mathrm{g}$, the usual adult concentration, by 20 weeks, only halfway through gestation. In all species the glycogen concentration in the skeletal muscles reaches adult levels early in 
gestation, and in those species where it is high at term, there is a steady rise during the last third of gestation.

Table I. Foetal tissue glycogen concentrations at term in different species

\begin{tabular}{|c|c|c|c|}
\hline \multirow[b]{2}{*}{ Species } & \multicolumn{3}{|c|}{ Glycogen concentration ( $\mathrm{mg} / \mathrm{g}$ wet tissue) } \\
\hline & Liver & $\begin{array}{l}\text { Skeletal } \\
\text { muscle }\end{array}$ & $\begin{array}{l}\text { Cardiac } \\
\text { muscle }\end{array}$ \\
\hline Rat & 90 & I I & 27 \\
\hline Rabbit & 40 & I5 & $\mathrm{I} 4$ \\
\hline Guinea-pig & 70 & 18 & 3 \\
\hline $\operatorname{Dog}$ & I I 5 & I 8 & 5 \\
\hline Cat & - & 一 & I3 \\
\hline Pig & 85 & 72 & $r_{5}$ \\
\hline Sheep & 80 & 38 & 16 \\
\hline Monkey & 90 & 30 & 10 \\
\hline Man & $9 \circ ?$ & $30 ?$ & $40 ?$ \\
\hline Usual adult range & $30-60$ & $7-15$ & $3-6$ \\
\hline
\end{tabular}

High concentrations of glycogen are also present in the foetal heart. The concentration is about ten times the adult level early in gestation, but later it usually falls and the level at term (Table I) varies with foetal 'maturity'. It is high in the rat, which is born naked, blind, and relatively helpless, but has fallen to the adult level in the guinea-pig, which is born looking and behaving like a miniature adult. Man may be exceptional in that the high concentration of early foetal life is maintained right up to term.

To some extent the accumulation of foetal glycogen can be influenced by nutrition. In rabbits the foetal liver glycogen concentration at term could be lowered by chronic restriction of the mother's food intake to $20-25 \%$ throughout the whole or the last third of pregnancy (Hafez, Lindsay \& Moustafa, 1967; Harding \& Shelley, 1967), or acute restriction to $10 \%$ or zero during the last 3 days (H. J. Shelley, unpublished experiments; term is $3 \mathrm{I}$ days). The foetal weights were usually reduced slightly, and the reduction in liver glycogen was greatest in the smallest foetuses where the liver weight was also unusually low relative to bodyweight. There was no effect on the cardiac or skeletal muscle glycogen concentration in the rabbits, but babies of low birth weight for the period of gestation who died during the neonatal period were found to have unusually low concentrations of glycogen in both the liver and the skeletal muscles (Shelley, 1968); such babies are thought to be the product of chronic placental insufficiency and intra-uterine malnutrition.

The factors responsible for the changes in tissue glycogen concentration at different stages of foetal development are not yet fully understood. In foetal liver, the only tissue studied in detail, the activity of the enzymes concerned with glycogen synthesis increases at about the time that glycogen begins to accumulate. The increase in enzyme activity and the rise in liver glycogen appear to depend on foetal pituitary and adrenal function; both cortisone and a pituitary or placental 'growth hormone' may be involved. 


\section{Carbohydrate metabolism after birth}

The diet of the neonate is very different from that of the foetus. The lipid-poor, carbohydrate-rich, trans-placental food supply is replaced by milk, which, except in equine species, has a lipid content $(\%)$ equal to or greater than its carbohydrate content. Even the nature of the carbohydrate has changed. Lactose has replaced glucose, and instead of being delivered straight into the blood via the placenta, it must be hydrolysed and absorbed from the gut as a mixture of glucose and galactose. Not surprisingly, the activity of the enzymes responsible for lactose hydrolysis ( $\beta$-galactosidase) in the small intestine rises shortly before birth and is very much higher during the suckling period than in the adult ('Table 2 ); the ability of the liver

Table 2. Changes in the activity of some enzymes of carbohydrate metabolism during the neonatal period

(The table includes both the trivial name of the enzyme and the reference number given in the Report of the Commission on Enzymes (1961). 1nt. Union Biochem. Symp. 20)

\begin{tabular}{|c|c|c|c|c|c|c|}
\hline $\begin{array}{l}\text { Metabolic } \\
\text { pathway }\end{array}$ & Enzyme & $\begin{array}{l}\text { Peak activity } \\
\text { (relative to } \\
\text { adult }=1 \text { ) }\end{array}$ & Rise begins & Fall occurs & Species & References \\
\hline \multirow[t]{4}{*}{ Lactose utilization } & $\begin{array}{l}\beta \text {-Galactosidase } \\
\left(E C_{3} \text {.2.1.23) }\right.\end{array}$ & $\begin{array}{l}\text { 10* } \\
\text { from birth }\end{array}$ & $\begin{array}{l}\text { Late } \\
\text { gestation }\end{array}$ & $\begin{array}{l}\text { Before and } \\
\text { during } \\
\text { weaning }\end{array}$ & Rat, rabbit & $\begin{array}{l}\text { Alvare } \angle \text { Sas }(\mathrm{r} 961) \\
\text { Doell \& Kretchmer } \\
(1962)\end{array}$ \\
\hline & \multirow[t]{2}{*}{$\begin{array}{l}\text { Galactokinase } \\
(E C \text { 2.7.1.6) }\end{array}$} & $\left\{\begin{array}{l}3^{-4} 4 \\
\text { at } 5^{-8} \text { days }\end{array}\right.$ & $\begin{array}{l}\text { Late } \\
\text { gestation }\end{array}$ & $\begin{array}{l}\text { Before and } \\
\text { during } \\
\text { weaning }\end{array}$ & Rat & $\begin{array}{l}\text { Cuatrecasas \& Segal } \\
\text { (1965) } \\
\text { Walker, Kahn \& Eaton }\end{array}$ \\
\hline & & $\begin{array}{l}\mathbf{I}-2 \text { ? } \\
\text { throughout } \\
\text { neonatal } \\
\text { life }\end{array}$ & $\begin{array}{l}\text { Early } \\
\text { gestation? }\end{array}$ & - & $\begin{array}{l}\text { Guinea- } \\
\text { pig }\end{array}$ & Walker et al. (1966) \\
\hline & $\begin{array}{l}\text { Galactose-I- } \\
\text { phosphate uridylyl } \\
\text { transferase } \\
(E C \text { 2.7.7.12) }\end{array}$ & $\begin{array}{l}5 \\
\text { at Io days }\end{array}$ & $\begin{array}{l}\text { Late } \\
\text { gestation }\end{array}$ & $\begin{array}{l}\text { During } \\
\text { weaning }\end{array}$ & Rat & Bertoli \& Segal (1966) \\
\hline \multirow[t]{2}{*}{ Glycogenolysis } & \multirow{2}{*}{$\begin{array}{l}\alpha \text {-Glucan } \\
\text { phosphorylase } \\
(E C 2.4 \cdot 1.1) \\
\text { Glucose-6- } \\
\text { phosphatase } \\
(E C \text { 3.1.3.9) }\end{array}$} & $\begin{array}{l}0.8-1.5 \\
\text { from birth }\end{array}$ & $\begin{array}{l}\text { Late } \\
\text { gestation }\end{array}$ & - & \multirow{2}{*}{$\begin{array}{l}\text { Rat, sheep, } \\
\text { guinea- } \\
\text { pig } \\
\text { Monkey } \\
\text { Rat, rabbit, } \\
\text { sheep, } \\
\text { guinea-pig } \\
\text { Mouse }\end{array}$} & $\begin{array}{l}\text { Ballard \& Oliver ( } \mathrm{rg}_{3} \text {, } \\
\text { 1965) } \\
\text { Kornfeld \& Brown (1963) }\end{array}$ \\
\hline & & $\begin{array}{l}2-3.5 \\
\text { at } I-2 \text { days }\end{array}$ & $\left.\begin{array}{l}\text { Early } \\
\text { gestation } \\
\text { Late } \\
\text { gestation } \\
\text { After bitth }\end{array}\right\}$ & $\begin{array}{l}\text { Before and } \\
\text { during } \\
\text { weaning }\end{array}$ & & Dawkins (1966) \\
\hline \multirow[t]{3}{*}{ Glyconeogenssis } & \multirow{3}{*}{$\begin{array}{l}\text { Phosphopyruvate } \\
\text { carboxylase } \\
\text { (EC 4.I.I.32) } \\
\text { Fructose-I-6- } \\
\text { diphosphatase } \\
\text { (EC 3.I.3.II) }\end{array}$} & $\begin{array}{l}2 \\
\text { from } 2 \text { days }\end{array}$ & After birth & $\begin{array}{l}\text { During } \\
\text { weaning }\end{array}$ & Rat & Vernon \& Walker (I968a) \\
\hline & & $\left\{\begin{array}{l}2-3 \\
\text { from } 5 \text { days }\end{array}\right.$ & After birth & \multirow{2}{*}{$\begin{array}{l}\text { During and } \\
\text { after weaning } \\
\qquad-\end{array}$} & \multirow{2}{*}{$\begin{array}{l}\text { Rat } \\
\text { Sheep }\end{array}$} & $\begin{array}{l}\text { Ballard \& Oliver (1962) } \\
\text { Vernon \& Walker (1968a) }\end{array}$ \\
\hline & & $\left\{\begin{array}{l}\mathrm{I} \text { at } 4 \\
\text { weeks } \dagger\end{array}\right.$ & $\begin{array}{l}\text { Late } \\
\text { gestation }\end{array}$ & & & Ballard \& Oliver (1965) \\
\hline
\end{tabular}

\footnotetext{
*The activity of the enzyme in the small intestine; all other activities refer to liver enzymes at a specified age after birth.

†The activity of fructose-r-6-diphosphatase in adult sheep liver is unusually high.
} 
to phosphorylate galactose (galactokinase activity) and convert it into glucose (galactose-I-phosphate uridylyltransferase activity) is also high at this time.

But lactation is seldom fully established until several days after birth and during this time the neonate must be largely dependent on his own reserves. In all species the liver glycogen concentration falls to about $10 \%$ of the level at term within a few hours of birth and remains low for several days. The activity of the enzymes necessary for liver glycogen mobilization is high (Table 2); the activities of $\alpha$ glucan phosphorylase (the enzyme responsible for phosphorolysis of glycogen) and glucose-6-phosphatase (which releases free glucose from glucose-6-phosphate) usually reach adult levels before term, but immediately after birth there is a dramatic rise in glucose-6-phosphatase activity to several times the adult level. The skeletal muscle glycogen concentration also falls after birth, but more slowly than the liver glycogen. In the general musculature adult levels are usually reached within $2-3$ days but the fall may be more rapid in actively working muscles such as those associated with respiration. There is no sudden change in cardiac glycogen in normal neonates, merely a gradual decline with increasing age, though the concentration may fall rapidly during fasting. The enzymes of glycogen metabolism have not been investigated in neonatal cardiac or skeletal muscle.

But the foetal glycogen reserves are sufficient to supply the energy needs of the newborn animal for only a few hours, and even when lactation becomes established, the amount of carbohydrate available is not large. Several changes occur which tend to conserve glucose during the suckling period. The large postnatal rise in plasma free fatty acids, which has been demonstrated repeatedly in lambs and babies, may suppress the rate of glucose uptake by the tissues (Randle, Garland, Hales \& Newsholme, ${ }^{1} 9^{6} 3$ ), and the fall in $\mathrm{RQ}$ from about $\mathrm{I} \cdot 0$ towards 0.7 , which occurs soon after birth in babies and guinca-pigs, suggests a shift from carbohydrate to fatty acid oxidation. In babies the plasma glycerol and ketone body levels also rise after birth, providing two further substrates for oxidation. The rise in ketone bodies is of particular interest in that brain slices from infant rats are able to oxidize acetoacetate as readily as glucose, suggesting that ketones may be an important substrate in the newborn for what has hitherto been considered a glucose-dependent tissue. Support for this concept is provided by recent studies on adult man (Cahill \& Owen, I 968) where, during fasting, cerebral glucose uptake falls and that of ketones rises until, after 40 days, more than $80 \%$ of the cerebral energy supply can be accounted for by ketone oxidation. The glycolytic ability of the liver falls rapidly in newborn rats, owing mainly to a decrease in the activity of the two rate-limiting enzymes hexokinase $\left(\begin{array}{lll}E C & 2.7 .1 .1\end{array}\right)$ and phosphofructokinase $\left(\begin{array}{lll}E C & 2.7 .1 .11\end{array}\right)$ and the rise in glucose-6-phosphatase. Pyruvate kinase ( $E C$ 2.7.1.40) activity also falls after birth in rat liver, and the dramatic fall in ATP citrate lyase (EC 4.I.3.6) to about one-twentieth of the adult activity (Vernon \& Walker, I $968 a$ ) is probably responsible for the large postnatal fall in hepatic lipogenesis (Taylor, Bailey $\&$ Bartley, 1967 ). In addition, the activities of two enzymes important for gluconeogenesis rise to high levels during the suckling period (Table 2) and, in both rats and sheep, the ability of the liver to convert pyruvate into glucose reaches about 
five times the adult rate at $2-3$ weeks after birth. The ability to oxidize amino acids and incorporate them into glucose or glycogen also develops over this period in puppies and rats (Yarnell et al. I966; Young \& Oliver, 1967), and since in liver from 5 -day-old rats the rate of glyconeogenesis from amino acids is twice that in adult liver, it is probable that these become the main precursors for gluconeogenesis. 'The net result of all these changes is that, providing the milk intake is adequate, the blood glucose and liver glycogen concentrations rise from the very low levels in the immediate postnatal period to reach adult values within $1-3$ weeks of birth.

At weaning relatively large amounts of carbohydrate become available in the diet and many of these changes are reversed (Table 2). Whereas the changes in $\beta$ galactosidase and galactokinase activities, appear to be independent of the presence or absence of lactose or galactose (Doell \& Kretchmer, 1962; Walker \& Khan, 1968), some of the other enzyme changes can be directly related to the diet. The effects of weaning on to artificial diets of variable composition have been studied intensively in rats (Walker, Kahn \& Eaton, 1966; Walker \& Eaton, 1967; Taylor et al. 1967; Vernon \& Walker, I968b). In general the change from milk to a glucose-rich diet promoted the activity of enzymes concerned with glucose utilization and lipogenesis and suppressed those involved in gluconeogenesis; weaning on to a carbohydratepoor, protein-rich diet led to the maintenance of a high rate of gluconeogenesis, while a high-lipid diet was especially effective in maintaining low activities of pyruvate kinase and ATP citrate lyase. The activity of glucokinase ( $E C$ 2.7.I.2, an enzyme phosphorylating glucose at high substrate concentration), which first appears in rat liver at weaning time, can also be influenced by the glucose content of the diet; it is of some interest that this enzyme is never present in sheep liver, where the dietary supply of glucose is always low because of fermentation in the rumen. But the carbohydrate content of natural diets is mostly in the form of polysaccharides, not glucose. The amylase activity of the rat pancreas rises during the weaning period and many of the intestinal disaccharidases first appear at this time. Whether their activity is affected by diet is uncertain. It is probable that, as with $\beta$-galactosidase, their appearance is decided by genetic rather than environmental factors.

\section{Carbohydrate metabolism during oxygen lack}

The role of carbohydrate metabolism in the well-oxygenated neonate has been discussed in some detail, but foetal and newborn animals probably run a greater risk of becoming short of oxygen than at any time in later life. In anoxia anaerobic glycolysis becomes the only major source of energy, and if this is inhibited the remarkable ability of newborn animals to survive in the absence of oxygen is greatly reduced; a newborn rat at $24^{\circ}$ will normally gasp for $5^{\circ} \mathrm{min}$ in $100 \% \mathrm{~N}_{2}$ but for only 3 min after pretreatment with iodoacetate, no longer than the normal adult. 'The prolonged anoxic survival of the untreated rats was partly due to hypothermia, but even at $36-38^{\circ}$, newborn rats will survive for $28 \mathrm{~min}$ and foetal sheep in midgestation for as long as $40 \mathrm{~min}$ (Table 3). This ability is lost with increasing 
'maturity' in both foetal and newborn animals, and that of lambs and guinea-pigs at term is little better than that of adults.

Table 3. Cardiac glycogen concentrations and anaerobic survival in foetal and infant animals

(The foetal animals were asphyxiated by tying the umbilical cord and covering the head with a salinefilled bag (sheep) or by total immersion in a saline bath after cutting the umbilical cord (rabbits). The infant animals were placed in $100 \% \mathrm{~N}_{2}$ (rats) or $95 \% \mathrm{~N}_{2}+5 \% \mathrm{CO}_{2}$ (guinea-pigs))

\begin{tabular}{|c|c|c|c|c|}
\hline Spccies & Age* & $\begin{array}{l}\text { Cardiac } \\
\text { glycogen } \\
(\mathrm{mg} / \mathrm{g})\end{array}$ & $\begin{array}{l}\text { Survival } \\
\text { at } 36-38^{\circ} \\
(\mathrm{min})\end{array}$ & References \\
\hline Sheep, foetal & $\begin{array}{l}58 \% \\
97 \%\end{array}$ & $\begin{array}{l}34 \\
18\end{array}$ & $\begin{array}{c}4 \circ \dagger \\
5\end{array}$ & $\begin{array}{l}\text { Dawes, Mott \& Shelley (1959) } \\
\text { Dawes, Jacobson, Mott, Shelley \& } \\
\text { Stafford ( } 1963 \text { ) }\end{array}$ \\
\hline Rabbit, foetal & $97 \%$ & 14 & 16 & $\begin{array}{l}\text { Campbell, Cross, Dawes \& Hyman } \\
\text { (I } 966 \text { ) }\end{array}$ \\
\hline \multirow[t]{5}{*}{ Rat, infant } & 0 & 22 & 28 & Stafford \& Weatherall (1960) \\
\hline & 2 & 18 & 21 & \\
\hline & 4 & 15 & 12 & \\
\hline & 8 & 12 & 9 & \\
\hline & 16 & 3 & 3 & \\
\hline Guinea-pig, infant & $\mathbf{I}$ & 3 & 3 & Miller, Miller \& Westin (I 664 ) \\
\hline
\end{tabular}

*Foetal ages are expressed as a percentage of the gestation period ( 147 days in sheep, 31 days in rabbits), infant ages as days after birth.

fImmature foetal lambs do not gasp regularly during asphyxia but they appeared to recover on untying the umbilical cord after $40 \mathrm{~min}$. The other values all refer to the time of last gasp; if oxygen is readmitted before this, the animals recover spontaneously.

During anoxia large amounts of lactate accumulate in the blood and tissues of newborn rats and mice and it was suggested that they might have an unusual capacity for glycolysis which was lost with increasing age. But the initial rate of lactate accumulation is similar in foetal lambs of different ages and in adult sheep, though their anoxic survival times are very different. It seems more likely that anoxic survival is determined, not by changes in enzyme activity, but by the availability of glucose or glycogen to a vital organ such as the heart or brain. The glycogen content of the brain is low at all ages, but that of the heart is extremely variable (Table I) and, within limits, is closely related to the ability to survive anoxia (Table 3). The cardiac glycogen concentration falls rapidly during anoxia; when the initial concentration is low it is soon exhausted, but when it is high the circulation can be maintained for a relatively long time.

Maintenance of the circulation is important for at least two reasons. Obviously it will be needed when oxygen is readmitted, but the brain is dependent on the circulation during anoxia. The time to last gasp of the isolated head of a newborn rat or of foetal monkeys asphyxiated by removing the heart is about half that of the intact animals. This dependence is related to the glucose supply to the brain, since in anoxic newborn rats the time to last gasp is also halved in insulin hypoglycaemia, although the initial cardiac glycogen concentration and the activity of the heart are unaffected. Conversely the time to last gasp can be prolonged by 
administering glucose to newborn rats from a litter where the liver glycogen is low and the blood glucose falls during anoxia. It is important to note that whenever large amounts of liver glycogen are present, the blood glucose rises during anoxia in foetal and newborn animals. But the buffering capacity of the blood is also important. The arterial $\mathrm{pH}$ falls rapidly during anoxia, owing to the high rate of lactic acid formation in the tissues, and glycolysis is gradually inhibited; when the arterial $\mathrm{pH}$ falls below 6.9 there is no further rise in tissue lactate. Thus in many animals death occurs before the cardiac glycogen is exhausted while the blood glucose concentration is still high. But if the artcrial $\mathrm{pH}$ is kept above $7 \cdot 2$ by infusing a base (sodium carbonate, tris or triethanolamine) and the blood glucose is kept high, the rate of lactate accumulation in asphyxiated foetal lambs in mid-gestation can be maintained at a high rate almost indefinitely and survival can be prolonged; in one experiment the foetus recovered after 80 min asphyxia, twice the usual survival time. But this treatment is less effective in mature foetal lambs and monkcys and there are other factors besides the glycolytic ability of the tissues which determine their tolerance to anoxia. 'There is good evidence to suggest that the basal energy requirements of immature tissues may be less than those of adult tissues, and that therefore they can survive for longer at the relatively low level of ATP production provided by anaerobic glycolysis.

\section{Conclusions}

Several aspects of foetal and neonatal carbohydrate metabolism have been neglected in this discussion. For instance, the role of fructose in the foetus, and of the high concentration of glycogen in some other tissues (placenta, lungs, intestinal mucosa) early in gestation, is not clear, and little is known for certain about the hormonal control of carbohydrate metabolism in the neonate. But our knowledge of other aspects of carbohydrate metabolism is advancing rapidly and it is pertinent to ask to what extent the information gained from animals can be applied to the human infant. Again our knowledge is scanty, but it suggests that, in general, the role of carbohydrate metabolism in the human nconate is similar to that in animals. But there appears to be one important difference which should be borne in mind. In primates, both man and monkcy, most of the developmental changes which have been investigated occur at a relatively early stage. For instance the rise in liver glycogen, the appearance of glucose-6-phosphatase activity, and the development of several intestinal disaccharidases occur in the second trimester in man. The remarkable ability of the human infant to survive premature delivery suggests that many other changes also occur at an early stage of gestation, and it is not safe to assume that, because an enzyme is absent from a newborn rat, the same is true of the newborn baby. But the low blood glucose levels often scen in newborn babies (see Neligan, 1969) and the changes with age in the response to glucagon suggest that the capacity for gluconeogenesis does not develop until after birth, and the slow rate of utilization of a glucose load suggests that, like the newborn rat, the newborn baby is doing all it can to conserve what glucose is available to it. 
REFERENCES

Alexander, D. P., Britton, H. G. \& Nixon, D. A. (x966a). F. Physiol., Lond. 185, 382.

Alexander, D. P., Britton, H. G. \& Nixon, D. A. (1 966b). \%. Physial., Lond. 186,100 .

Alexander, D. P., Brition, H. G. \& Nixon, D. A. (1969). In Perinatal Medicine. [P. J. Huntingford, K. A. Tüter and E. Saling, editors.] Stuttgart: Thicme Vorlag. (In the Press.)

Alvarez, A. E. Sas, J. (1961). Nalure, Lond. 190,826.

Ballard, F. J. \& Oliver, T. 'T. (Ig62). Natwe, lond. 195, 498.

Ballard, F. J. \& Oliver, I. T. (1963). Biochim. biophys. Acte 7T, 578 .

Ballard, F. J. \& Oliver, I. T. (1065). Biochem. Y. 95, I9г.

Bertoli, D. \& Segal, S. (1 g66). F. biol. Chem. 241, 4023.

Cahill, G. F. Ir \& Owen, O. E. (1968). In Carbohydrate Metabolism and Its Disorders. Vol, I, p. 497.

[F. Dickens, P. J. Randle and W. J. Whelan, editors.] London and New York: Academic Press Inc.

Campbell, A. G. M., Cross, K. W., Dawes, G. S. \& Hyman, A. I. (x966). F. Pedial. 68, I 53.

Cuatrecasas, P. \& Segal, S. (I065). F. biol. Chem. 240, 2382 .

Dawes, G. S., Jacobson, H. N., Mott, J. C., Shelley, H. J. \& Stafford, A. (1963). Y. Physiol., Lond. $169,167$.

Dawes, G. S., Mott, J. C. \& Shelley, H. J. (1959). F. Physiol, Lond. ז46, 516.

Dawes, G. S. \& Shelley, 1Y. J. (1958). In Carbohydrate Metabolism and its Disorders. Vol. 2, p. 87. [F. Dickens, P. I. Randle and W. I. Whelan, editors.] London and New York: Academic Press Inc.

Dawkins, M. J. R. (г966). Br. med. Bull. 22, 27.

Doell, R. G. \& Kretchmer, N. (1962). Biochim. biophys. Acta 62, 353 .

Hafez, E. S. F., Tindsay, D. R. \& Moustafa, I. A. (ig67). Am. F. vet. Res. 28, i 53.

Harding, P. G. R. \& Shelley, H. J. (1967). In Intra-uterine Dangers to the Foetus, p. 529. [J. Horsky and Z. K. Stembera, editors.] Amsterdam: Excerpta Medica Foundation.

Koren, Z. \& Shafrit, 5. (1964). Proc. Soc exp. Biol. Med. Ix6, 4ा I.

Komfeld, R. \& Brown, D. H. (;963). F. biol. Chem. $\mathbf{3} 8, \mathrm{~s} 604$.

Miller, J. A. Jr, Miller, F. S. \& Westin, B. (1964). Biol. Neonat. 6, $14^{8}$.

Neligan, G. A. (rg6o). Proc. Nutr, Soc. $28,49$.

Popják, G. E Beecknans, M. L. (10 jo). Biochem. \%. 46, 54.7.

Randle, P. J., Garland, P. B., Hales, C. X. \& Newsholme, E. A. (1963). Lancet i, 785 .

Shelley, H. J. (ro69). In Perinatal Medicine. [P. J. Huntingford, K. A. Hüter and E. Saling, editors.] Stuttgart: Thicme Verlag. (In the Press.)

Stafford, A. \& Weatherall, J. A. C. (1960). I. Physiol., Lond. r53, 457.

Taylor, C. B., Bailcy, E. \& Bartley, W. (1967). Biochem. F. 105, 717.

Vernon, R. G. \& Walker, D. G. (1968a). Biochem. \%. 106, 32. 1.

Vemon, R. G. \& Walker, D. G. (1068b). Biochem. \%. no6, 33 I.

Walker, D. G. (I 68). In Carbokydrate Metabolisn and Its Disorders. Vol. I, p. 465. [F. Dickens, P. J. Randle and W. J. Whelan, editors.] London and New York: Academic Press Inc.

Walker, D. G. \& Iiaton, S. W. (r067). Biochem. \%. ro5, 77 I.

Walker, D. G. \& Khan, H. H. (1968). Biochem. \%. 108, r60.

Walker, D. G., Khan, H. H. \& Eaton, S. W. (1966). Biol. Neonat. 9, 224.

Wolf, H., Šabata, V., Frerichs, H. \& Melichar, V. (1969). In Perinatal Medicine. [P. I. Huntingford K. A. Huter and E. Saling, editors. $]$ Stuttgart: 'Thieme Verlag. (In the Press.)

Yarnell, G. R., Nelson, P. A. \&. Wugle, S. R. (1966). Fedn Proc. Fedn Am. Socs exp. Biol. 25, 449,

Young, D. \& Oliver, I. T. (1967). Biochem. F. 103, 744 .

\section{Hypoglycaemia in the newly born baby}

By G. A. NeLigan, Department of Child Health, University of Newcastle upon Tyne

If hypoglycaemia is defined as an abnormally low blood sugar level which may cause clinically recognizable symptoms, and if we know that young mammals can regularly tolerate the remarkably low levels of blood sugar which have repeatedly been found during the acute nutritional crisis which follows separation from the placenta, we might be forgiven for doubting if the newly born human baby can 